\title{
THE IMPACT OF BREXIT ON SECURITY AND DEFENCE MULTILATERALISM: MORE COOPERATION OR OVERLAPPING INTERESTS?
}

\section{Ana Isabel XAVIER*}

\section{Abstract}

One of the most striking questions raised by Brexit is undoubtedly related to security and defence. What should we expect from the United Kingdom (UK) in the collective and multilateral efforts within the European Union (EU) and North Atlantic Treaty Organisation (NATO) after Brexit? This article aims to contribute to an answer by arguing that, in the security and defence field, Brexit hardly represents a threat to NATO or the EU. Instead, it offers an opportunity to readjust priorities and investments towards an effective multilateralism, both European and transatlantic. The paper argues that, faced with an apparent overlap of the threats and challenges shaped by the strategic environment and the priority concerns of both organisations, it is expected that the UK will continue to be engaged in the EU common security and defence policy's (CSDP) civilian missions and military operations as a third country, as well as enhance NATO's commitments in the aftermath of the implementation of the 2016 Warsaw Declaration.

Keywords: Brexit, European Union, NATO, Multilateralism, Security and Defence

\footnotetext{
* Assistant Professor in International Relations in UAL (Universidade Autónoma de Lisboa) and ISCTE-IUL (University Institute of Lisbon) and a Researcher in Observare - Observatory of external relations, CEI-IUL (Centre of International Studies at ISCTE-IUL) and CISD-IUM (Research Centre in Security and Defence of the Portuguese Military University Institute). e-mail: aixavier@autonoma.pt | ana.isabel.xavier@iscte-iul.pt
} 


\section{BREXIT'INN GÜVENLIIK VE SAVUNMA COK TARAFLILIĞINA ETKİSI: DAHA FAZLA İŞBİRLİĞI YA DA ÖRTÜŞEN ÇIKARLAR}

$\ddot{O}_{z}$

Brexit ile ilgili en çarpıcı sorulardan biri de hiç kuşkusuz savunma ve güvenlikle ilgilidir: Brexit sonrasında Birleşik Krallık'tan hem Kuzey Atlantik Antlaşma Örgütü (NATO) hem de Avrupa Birliği (AB) dahilindeki kollektifve çok tarafl teşebbüslerle ilgili olarak ne beklemeliyiz? Bu makale, Brexit'in güvenlik ve savunma alanlarında NATO'ya veya AB'ye bir tehdit teşkil etmediği iddiasiyla bu sorunun cevabina katkıda bulunmayı amaçlamaktadır. Bilakis, Brexit hem Avrupa hem de Atlantik ötesi etkin bir 'çok taraflllık' yönünde önceliklerin ve yatırımların yeniden ayarlaması için bir firsat sunmaktadır. Makale stratejik çevrenin ve her iki organizasyonun önceliklerinin şekillendirdiği bir tehdit ve zorluklar örtüşmesiyle karşı karşıya kalan BK'den AB'nin ortak güvenlik ve savunma politikasının sivil misyonları ve askeri operasyonlarına üçüncü ülke olarak angaje olmasının yanısıra, 2016 Varşova Bildirgesi'nin yürürlüğe girmesinin ertesinde NATO'nun taahhütlerini güçlendirmesinin beklendiğini iddia etmektedir.

Anahtar Kelimeler: Brexit, Avrupa Birliği, NATO, Çok taraflılı, Güvenlik ve Savunma

\section{Introduction}

The relationship between the European Union (EU) and the United Kingdom (UK) has long been peculiar. The formal accession to the European Communities took effect only on the third application on January 1, 1973. The UK first applied in 1961, but French President Charles de Gaulle vetoed, arguing that matters of sovereignty were not entirely clarified. Throughout the years, the outer-tier status (Oliver, 2015: 17) that UK politicians always nourished in a bigger or smaller scale has been best illustrated by some opt-outs “... backed by British public opinion, [that] have generally supported a shallower version of economic and political integration" (Wallace, 2012: 540). In addition to the Economic and Monetary Union and the Schengen Agreement, during the Lisbon Treaty negotiation process, the UK has also invoked clauses of exclusion or nonparticipation in two more areas of European policy harmonization: the area of Security, Freedom and Justice; and the Charter of Fundamental Rights of the European Union.

More recently, on January 23, 2013, David Cameron made a promise: if he wins the 2015 election, a referendum would be held on whether the UK should 
remain in the European Union. This promise was not only fulfilled but was also politically legitimized by an absolute majority of votes. Later, Cameron would also say that if he lost the referendum, he would not leave office and would immediately activate article 50 of the Treaty of Lisbon, assuming all the responsibility for the negotiations with the European institutions.

On June 23, 2016, a referendum on European Union membership took place in the United Kingdom, with $51.89 \%$ of voters in favour of Brexit and $48.11 \%$ in favour of remaining in the EU. The traditionally labour-based electorates voted in favour of Brexit: $61,3 \%$ in Sunderland or $65,5 \%$ in Middlesbrough (BBC, 2016) are good examples of how the Labour Party's strength has given way to UK's independence party (UKIP)'s rhetoric on immigration or the National Health Service. Cameron was also criticised for lack of involvement in the campaign, which led to his resignation and the nomination of Theresa May with no general elections whatsoever.

On March 29, 2017, Prime Minister Theresa May addressed a letter to European Council President Donald Tusk, triggering article 50 and, consequently, the beginning of the Brexit negotiations: "I hereby notify the European Council in accordance with Article 50(2) of the Treaty on European Union of the United Kingdom's intention to withdraw from the European Union" (Sky News, 2017).

In the same document, Theresa May clarifies the need to agree on a deep and special partnership between the UK and the EU, taking into account that Europe's security, she argued, "is more fragile today than at any time since the end of the Cold War" (Sky News, 2017). Earlier, in February that year, an official document had been released to explain that a new partnership with the EU is in British minds through a "...smooth, mutually beneficial exit [that] will require a coherent and coordinated approach on both sides" (HM Government, 2017).

More than one year after the beginning of the negotiations, it is still hard to speculate what will be the ultimate scenario due to next October with effects ahead March 2019: a hard or harsh Brexit deal (aiming at a Canada-style trade deal), a soft Brexit deal (whether just staying in the EU's single market like Norway or also staying in its customs union), or a no deal/no Brexit/Bremain (Hughes, 2017: 3-11; Morillas, 2016: 2-16).

The debate and negotiations in the last few months have been focusing mainly on three main areas: rights for EU nationals living and/or working in the UK and UK nationals living and/or working in the EU; the institutional relationship with Northern Ireland; and free trade with European markets. However, it is worth exploring (based on the multiple political and security challenges of a competing multipolar world) what to expect of the UK in terms of collective and multilateral efforts within the EU and among NATO allies. 
It is in fact, within the multilateral framework, that the assessment of the impact on the process of negotiations must be considered. Therefore, the negotiation process in security and defence matters cannot be limited to a traditional military approach, considering that the challenges of radicalization, terrorism, cyber, resilience, reconstruction, or state-building are not necessarily solved nor mitigated by the strict use of military capabilities. The development of joined-up civilian and military synergies to tackle external crises will always be needed to address the strategic environment in which the negotiations will take place.

Bearing all these background and exploratory questions in mind, this paper aims to contribute to this complex debate, arguing that Brexit (when and if it actually happens) should reinforce both the European security and defence and NATO cooperative alliance. We will then conclude that, rather than being a threat, Brexit is an opportunity for the UK (and the EU) to realign priorities in terms of investments and commitments in the security and defence field (Calcara, 2017), strengthening multilateralism and strategic cooperation with the $27 \mathrm{EU}$ member states and among NATO allies.

For the purpose of this article, methodology options were limited to a literature review on security and defence and the discourse analysis of official documents from the UK government and EU institutions.

\section{The United Kingdom, the European Union and the Common Security and Defence Policy (CSDP)}

According to the European Treaties, member states are supposed to support the foreign security policy actively and unreservedly in the spirit of mutual loyalty and solidarity. By nature, CSDP is intergovernmental and it is up to the member states to make a sovereign decision on the domains of foreign policy, international security and cooperation in the field of defence. Therefore, as Besch (2016:8) recalls, "[e]ven after Brexit, the EU and the UK will have a mutual interest in close defence and security relations".

Although investment on defence as a proportion of GDP has dropped "by approximately 1 per cent every decade since 1960, the UK still ranks in the top five countries for defence expenditure globally" (Black et all, 2017: 25), and it is worth recalling that

[a]long with France, it is the only other EU state with a sizeable military that is both experienced and able to operate independently - even if in a limited sense - beyond Europe. Britain's soft power, along with other aspects of its power such as in intelligence, diplomacy and humanitarian aid, remain considerable (Oliver, 2015: 22). 
So, a first question seems relevant to be raised: what will be the Brexit's real effect on CSDP $?^{1}$ In what concerns current British commitments in the EU, it is estimated to support the EU Battlegroups concept through the provision of troops and equipment; contribute to EU operations and run EUNAVFOR Operation Atalanta's operational HQ out of Northwood. (Black et al, 2017: 30).

However, two trends seem to collide. For Major and Molling (2017:4), the Brexit's effect on the EU's CSDP is clear: a theoretical loss of military capabilities and aspirations to become a military power, a practical loss of political power and a gain in institutional governance. In fact, if, on one hand, the EU might lose an operational weight in the CSDP with nuclear deterrent capacity, on the other it is worth recalling how reluctant the UK has always been to accept further integration of EU's defence and major institutional reforms, permanently blocking the deployment of CSDP missions and operations, vetoing the aspiration of a permanent operational headquarters, and opposing to an increase of the European Defence Agency (EDA)'s budget and the common funding of the Athena mechanism. No wonder that for Angelini, "[t]he disappearance of the British veto on these matters could bring renewed momentum to initiatives that have been long blocked and open the door to new proposals" (2016).

Indeed, with Brexit, the adjustment of the intergovernmental governance model within the CSDP may tend to favour the leadership of other member states in this field. The absence of a strong opponent voice to the development of a military structure within the EU could in fact enhance the militarization of the CSDP.

In addition, despite its international credibility as a military actor in the last decade, the UK's participation in CSDP missions and operations or the deployment of personnel and equipment to the Northwood HQ for the EU operation Atalanta ${ }^{2}$ has been disproportionally small. The UK's contribution of personnel to date has accounted for just $2.3 \%$ of total Member State contributions (House of Lords, 2018: 3). In addition, "[t]he UK's financial contribution to civilian missions is only of $15 \%$. As $85-90 \%$ of the costs of military missions and

\footnotetext{
1 For futher information please see https://eeas.europa.eu/topics/common-security-anddefence-policy-csdp_en (last accessed 14 July 2018).

${ }^{2}$ Another interesting aspect that might be an opportunity for other member states is that Operation Atalanta on maritime security and anti-piracy in the Indian Ocean is run from EUNAVFOR HQ in Northwood, UK. Once Brexit occurs, the Headquarters will need to be transferred, which can provide an opportunity for other member states to consider applying for a command structure with the same characteristics as the United Kingdom. In this context, it should be recalled that, in addition to the UK, France, Italy, Greece, and Germany have expressed their intention in the past to provide headquarters for CSDP operations. In addition, regardless of the future of Operation Atalanta, it may be necessary to maintain an Operational Command for maritime operations.
} 
operations are financed by the participating countries, the UK's $17 \%$ contribution to the common costs of military missions and operations is relatively lower" (House of Lords, 2018: 42).

This argument is even stronger if we compare it to the military capabilities at stake, unlike the involvement in NATO and the enhancement of bilateral relations in the framework of defence. In fact, following the withdrawal of military forces from Iraq and Afghanistan, the UK has reassessed its strategic priorities (Whitman, 2016: 45), privileging a stronger cooperation within NATO and insisting on an Anglo-French alliance for further coordination within the EU. If in 2006 the UK only deployed operations in Chad and the Horn of Africa, in 2014 the UK was occupying the fifth place in military operations and the seventh in civilian missions, strengthening bilateral relations in defence and greater engagement in NATO. No wonder that the House of Lords acknowledges that " $[t]$ he UK's role in CSDP missions and operations has been more a 'manager' than a "player"' (2018: 70).

According to the Military Balance 2016, the United Kingdom's participation in CSDP missions and operations included: EUFOR ALTHEA (Bosnia and Herzegovina) with 31 elements; EUTM Mali (Mali) with 26 elements; EUNAVFORMED/Sophia (Mediterranean) with 1 FFGHM; and EUTM Somalia (Somalia) with 5 elements. In addition, the UK has also contributed regularly to the EU Battlegroups, as well as to the EU Military Rapid Response Mechanism. In $2017 / 2018$, within the 16 ongoing civilian missions and military operations, the UK participates with 6 personnel in EUAM Ukraine, 8 personnel in EUMM Georgia, 1 personnel in EUPOL COPPS, 8 personnel in EULEX Kosovo, 6 personnel in EUFOR Althea, 4 personnel in EUTM Somalia, 2 personnel in EUCAP Somalia, 6 personnel in EUNAVFOR Med, and 8 personnel in EUTM Mali. The most representative participation is due to the EUNAVFOR Somalia (Operation Atalanta) with operation commander and 56 UK personnel. However, no further representation is assured in EUCAP Sahel Mali, EUCAP Sahel Niger, EUTM RCA, EUAM Iraq, EUBAM Libya or EUBAM Rafah (House of Lords, 2018: 18).

Also, it is true that the UK represents the biggest military capability resources within the EU - a total of 154,700 assets, of which 88300 (army), 32500 (Navy), 33900 (Air Force) and 84000 in retreat. However, those numbers are not very impressive if we bear in mind that the UK is the EU's member state with the biggest military assets and capabilities: in a total of 154700,88300 come from 
the army, 32500 from the Navy and 33900 from the Air Force, while 84000 are part of a strategic reserve ${ }^{3}$.

In addition, it is rather interesting to note that most of the UK's commitments in the security and defence field are bilateral or in other multilateral forums besides the EU (Black et al, 2017: 31). It is therefore expected that the Brexit's impact on an effective support and active participation in CSDP missions and operations will be less than initially estimated and to some extent even residual. First, because the UK can still participate with resources and equipment in CSDP Operations as a third country. In fact, the UK has already mentioned its intention to continue to contribute with resources and equipment to CSDP missions, as well as to participate in pooling and sharing ${ }^{4}$ initiatives. In brief, given the fact that security and defence is a strategic issue for the UK, no major changes are expected at this level.

Second, because

[a]s a nation-state with significant diplomatic and military resources, the UK's foreign, security and defence policy has never been solely pursued through the EU but via a variety of institutions (most the North Atlantic Treaty Organisation and the United Nations) and key bilateral relationships, such as that with the United States. Consequently, the detachment of the UK's foreign, security and defence policy from the EU's Common Foreign and Security Policy (CFSP) and Common Security and Defence Policy (CSDP) will be less complicated than in other areas of public policy (Whitman, 2016:44).

Moreover, Brexit may not only intensify the EU military capabilities to evolve but may also encourage stronger cooperation between member states towards a strategic and competitive security and defence. In short, the Brexit's impact on the CSDP will be more symbolic (losing a military actor and an effective contributor to the EU's comprehensive approach in terms of crisis prevention,

3 Please see Black, 2017 and https://www.globalfirepower.com/country-military-strengthdetail.asp?country_id= united-kingdom (accessed 5 January 2018).

${ }^{4}$ At their informal summit in Ghent, Belgium, in autumn 2010, the defence ministers of the European Union launched an initiative called Pooling and Sharing, committing both to provide a capability that is missing in other member states (share) and to coordinate the capabilities to make them available on a more constant basis or in greater numbers compared to individual (pool). Regarding Pooling \& Sharing projects, UK currently participates in: Airworthiness; Ammunition Qualification ENNSA; Defence Test \& Evaluation Base; Air to Air Refuelling, European Air Transport Fleet (EATF) Training Activities EATT EAATTC EATIC EATS; Governmental Satellite Communications (GOVSATCOM); Helicopter Exercise Program (HEP); Maritime Surveillance (MARSUR) Networking; and Remotely Piloted Aircraft Systems (RPAS). 
stabilization and resolution and conflict, but also cooperation and development) than effective.

However, it is worth anticipating some difficulties concerning the support to peace missions, security sector reform, development, and contribution to the European Development Fund ${ }^{5}$ and the regional trust funds in response to specific crisis $^{6}$ managed by the European Commission. Brexit will inevitably lead to a redistribution of EU member states' contributions, first and foremost to the European Development Fund, essential to a sustainable peace in a crisis or postconflict context. In turn, the implementation of a high-Level Goal should not be affected by Brexit, as in 1999 the level of political, strategic, and operational ambition was agreed only among 15 member states that did not include the UK.

In what concerns the permanent structured cooperation, Brexit might enhance strategic cooperation among the most capable participating states as, since the Lisbon Treaty negotiations, the UK has always been opposed to this mechanism. The extension of $\mathrm{PESCO}^{7}$ to the area of defence is a major issue at this moment in the EU, as the Franco-German proposal to deepen the integration of European defence and European defence industries, presented in June 2017, clearly illustrates (Koenig and Walter-Franke, 2017). The same integrationist driver can be expanded to the enhanced cooperation in areas such as the CFSP and CSDP, by a group of at least nine member states who express their will and have the capacity to do so, sidestepping from the unanimity procedures.

Regarding the European institutions, Brexit will be significantly felt in the permanent political and military crisis management structure and its decisionmaking process, namely: in bodies with national representation, such as the Political and Security Committee (PSC); the Military Committee (EUMC) and the Committee on Civilian Aspects of Crisis Management (CIVCOM); in the planning bodies, such as the EU Military Staff (EUMS) and the Planning and Crisis Management Directorate (CMPD); and in Agencies, such as the European Defence Agency (EDA), the European Satellite Centre (EUSC), the EU Institute for Security Studies (EU ISS), and the European Security and Defence College

\footnotetext{
${ }^{5}$ European Development Fund (EDF) was launched in 1959. It aims to provide development aid to African, Caribbean and Pacific counties and to oversea countries (ACP)and territories (OCTs). For further information please see https://ec.europa.eu/europeaid/ node/1079_fr (accessed 4 July 2018)

6 E.g. Syria or Africa

${ }^{7}$ The permanent Structured Cooperation on security and defence (PESCO), was outlined in the Treaty of the EU, Articles 42 (6) and 46, as well as Protocol 10 and aims to enhance coordination and increase investment in defence and cooperation in developing autonomous defence capabilities. A detailed factsheet is provided in https://eeas.europa.eu/headquarters/ headquarters-Homepage/34226/permanent-structured-cooperation-pesco-factsheet_en (accessed 4 July 2018).
} 
(EUSDC). In fact, Brexit will leave the positions occupied by British officials seconded to the European External Action Service, European Commission, Military Committee, and Military Staff of the European Union available.

On financing, a major impact will be felt with an updated revision of the member states' contributions to the European Defence Agency (EDA)'s budget, Athena Mechanism, ${ }^{8}$ or European Union Satellite Centre (SATCEN) ${ }^{9}$ common costs, which will represent a bigger financial burden for the 27 member states. Regarding the EDA Budget, between 2004 and 2013, the UK was the third largest contributor with $14.1208 \%$ of the total EDA budget (Faleg, 2016). The EDA budget for 2017 included the contribution of the United Kingdom, but for the following years the UK's contribution will be split between the remaining member states (excluding Denmark), and adjusted according to the percentage of GDP, for instance, increasing the other member states' national contributions to the EDA budget.

In terms of EDA projects (capacity development, ${ }^{10}$ procurement, market integration, and research), Brexit might encourage the development of a European Defence Technological and Industrial strategy, allowing for a more structured cooperation in defence. As Biscop and Coelmont recall,

The main problem of Europe's armed forces is fragmentation: limited defence budgets spent on a plethora of small-scale capabilities result in disproportionately high spending on -overhead (and useless intraEuropean duplications) and, consequently, less spending on deployable capabilities and actual operations. To overcome this inefficiency, multinational cooperation is a must (2010: 5).

Therefore, three scenarios may arise for the UK's post-Brexit engagement in EDA (Black et al, 2017: 46): first, Exit; second, Associate status (through administrative Arrangements, like with Norway, Switzerland, Serbia or Ukraine); or third, Full membership (allowing a greater input in EU decision making on defence). So far, the second scenario seems to be the most realistic one.

\footnotetext{
${ }^{8}$ Athena is a mechanism which handles the financing of common costs relating to EU military operations under the EU's common security and defence policy (CSDP). Please see https://www.consilium.europa.eu/en/policies/athena/ (accessed 20 July 2018).

${ }^{9}$ For further information please see https://www.satcen.europa.eu/page/the_centre (accessed 20 July 2018).

${ }^{10}$ Regarding Capacity Development, UK currently participates in the following EDA projects: Helicopter Training and Qualification; Medium Transport Helicopters; Helicopter Safety; Armoured Wheeled Vehicles; Protected Transport Vehicles; Soldier Systems; Military Studies; C-IED and EOD; Surface Combatant Vessels; Auxiliary Ships - Logistic Support; Deployable Field Camp Solutions. It is estimated that the UK "burden" in terms of the EU Force Catalogue corresponds to $20 \%$ of the total.
} 
In fact, the UK may continue, through association agreements between the 26 participating states ${ }^{11}$ in EDA, to take part in collaborative projects in support of a European Defence Technological and Industrial Base. It can mitigate barriers to trade in technology and equipment exports, while at the same time benefiting from exemptions and tax incentives for collaborative projects developed by the European Defence Agency.

A revision of the Letter of Intent on the Framework Agreement signed in 2000 and open to the other European states commits the UK, France, Germany, Italy, Spain, and Sweden to cooperate in close coordination with EDA, which could encourage the UK to continue its participation in the Agency's projects. In addition, within the EU-NATO Cooperation Declaration, the promotion of contacts between the NATO Allied Command Transformation (in which the UK takes part) and EDA could boost confidence and foster the exchange of specialized knowledge and information between the two international organisations.

Also, possible scenarios for post-Brexit public procurement include full access to the European single market through membership of the EEA or the exit from the single market (Black et al, 2017: 48). Both scenarios show big disadvantages for both sides: on one hand, new EU legislation on public procurement could be constrained by British blockings; on the other hand, the UK could also be obliged to leave the government Procurement Agreement (GPA), "a non-obligatory agreement between members of the WTO regulating the basis on which GPA members give foreign suppliers access to their governmental procurement markets" (Black et al, 2017: 48).

Therefore, Brexit could increase fragmentation in the European defence technological and industrial base faced by a difficult situation. It is worth recalling that most defence delivery is carried out by only six countries (France, Germany, Italy, Spain, Sweden, and the United Kingdom) which signed a letter of intention to create this framework. Also, directives $2009 / 43 / \mathrm{EC}^{12}$ and $2009 / 81 / \mathrm{EC}^{13}$ sustain the backbone of the system, regulating the procedures for obtaining production licenses, contractual procedures and standards which minimize discrimination and increase transparency in this market.

\footnotetext{
${ }^{11}$ All EU member states participate in the European defence component except Denmark.

${ }^{12}$ It aims to simplify terms and conditions of transfers of defence-related products within the Community. Please see https://eur-lex.europa.eu/legal-content/EN/TXT/PDF/?uri=CELEX: 32009L0043\& from=EN (accessed 20 July 2018).

${ }^{13}$ It sets out EU procurement rules, adapted to the specificities of the defence and security sectors. Please see https://eur-lex.europa.eu/legal-content/EN/TXT/PDF/?uri=CELEX: 32009L0081\&from=en (accessed 20 July 2018).
} 
On the other hand, Brexit will also have a major impact on research and development investment since, within the framework of EDA, the UK participates in some important projects, along with other member states, such as: the European Strategic Multi-Role Tanker Transport Initiative; ${ }^{14}$ Military Implementation of the Single European Sky/ Single Air Traffic Management Research program with the creation of a "SESAR cell"; and maritime Surveillance Networking - Adaptive Maintenance. ${ }^{15}$

After identifying the main challenges and constrains to the European security and defence, it seems clear that all depends whether our approach is pro-brexit, pro-remain, pro-UK, or pro-EU. This is the argument of Josef Batorá quoted by Uttley and Wilkinson (2016: 575-584) when sketching four assumptions for defence procurement and the defence industry in the Brexit debates. These assumptions are that: "leaving will not undermine the UK's defence procurement options or industrial capabilities (pro-UK, pro-Brexit)"; "there is nothing to lose by staying in, but there are manifold risks for the UK in leaving (pro-UK, proremain)";"leaving will undermine the EU's defence industry so that the EU and the UK will rely on the US to an even greater extent (pro-EU, pro-remain)"; "and a British exit will remove a barrier to other member states' desire for an 'ever closer union' and a European Defence Union (pro-EU, pro-Brexit)" (Uttley and Wilkinson, 2016: 575-584).

\section{The United Kingdom and EU-NATO Cooperation}

Back in 1949, when the North Atlantic Treaty Organization (NATO) was created as an intergovernmental military alliance between several North American and European states, the UK was one of the twelve founding members and it is, still, one of the most active and respectful members of the alliance. Moreover, along with the United States and France, the UK is a permanent member of the United Nations Security Council, with veto power and officially a nuclear-weapon state.

Within the framework of EU-NATO cooperation and among NATO allies in specific, enhancing the cooperative links within the military alliance will always be a strategic issue for the UK, also to balance the fact that

[t]he British have been more circumspect about the role of the EU (..) The questions for the British have repeatedly been: when and whether the EU as a whole would prove capable of action; what should be the division of

\footnotetext{
${ }^{14}$ Seeks a comprehensive approach in aircraft refuelling in flight, aimed to increase overall capacity, reduce fleet dispersion and optimize available resources.

15 For SESAR please see https://eda.europa.eu/what-we-do/our-current-priorities/eu-policies. Maritime Surveillance (MARSUR) network enables the sharing of information, both in basic and automated mode. For further information see https://www.eda.europa.eu/what-wedo/activities/activities-search/maritime-surveillance-(marsur) (accessed 20 July 2018).
} 
labour between the EU and NATO; and when action would depend on a coalition of the willing, often involving the US (Uttley and Wilkinson, 2016: 543).

In fact, faced with an apparent overlapping interest of both organizations, the issue of EU-NATO cooperation is assuming greater importance with the implementation of the Warsaw Declaration, ${ }^{16}$ as well as with the development of a more solid military structure within the CSDP.

Likewise, the Berlin Plus mechanism, ${ }^{17}$ which facilitates access to NATO command, control, information, and communication structures by the EU, should not be affected, as British responsible parties already gave positive signs in favour of cooperative initiatives that complement and strengthen European and transatlantic defence.

Under the 2002 EU-NATO Declaration on CSDP, ${ }^{18}$ the establishment of a planning and conduct cell for CSDP operations within SHAPE, in liaison with the EU Military Committee, as well as the presence of NATO liaison officers in the Joint Staff of the European Union in Brussels could facilitate the continuous presence of British military and other experts in the planning and conduct of CSDP missions and operations.

Within the EU framework, the impact on defence should be minor, given that the UK's participation in CSDP missions and operations has traditionally been very small. In fact, the UK's participation in CSDP missions and operations was, according to the latest data provided by the Military Balance 2016, about 62 elements, a number that can be considered quite low considering that the UK is the member state with the greatest resources in terms of military assets and capabilities across the EU. Therefore, Brexit can provide an autonomous ${ }^{19}$ strategic role for the EU, although in complementarity with NATO. We must point out that in certain situations the British position had allowed for a desirable 'balance', which means that Brexit will necessarily leave an empty seat to be

16 The Warsaw declaration on Transatlantic Security, issued by the Heads of State and Government participating in the meeting of the North Atlantic Council in Warsaw 8-9 July 2016, can be found here: https://www.nato.int/cps/en/natohq/official_texts_133168.htm (accessed 20 May 2018).

${ }^{17}$ The Berlin Plus agreement consists of a comprehensive package of agreements between NATO and the EU on 16 December 2002, allowing the EU to draw on some of NATO's military assets in its own peacekeeping operations. More info provided in www.europarl.europa.eu/.../2004.../berlinplus_/berlinplus_en.pdf ( accessed 13 June 2018).

18 Please see https://www.nato.int/cps/en/natolive/official_texts_19544.htm ( accessed 20 May 2018).

${ }^{19}$ It is also important to pay due attention to the US position on the EU's claims to develop CSDP, as there has been a recent convergence in defence policy between France, Germany, the United Kingdom and, consequently, the US, which would like to see Europe become more autonomous in the field of defence (Keohane, 2017). 
occupied by the Franco-German hub or strategic coalitions between the southern or eastern countries.

However, if some believe that "[w]ith the United Kingdom out, independent European defence will be nothing but an elusive concept more than ever before" (Ondrejcsák, 2016:1), others argue that

[i]n the narrowest of terms, European security and defence are areas in which a British exit from the European Union would have comparatively little effect. (...) Furthermore, NATO remains Britain's multilateral defence forum of choice, something that Brexit need not change. (Heisbourg, 2016: 13).

Also, according to Oliver and Williams (2016: 547),

A Brexit has the potential to make a significant impact on transatlantic relations. It will change both the UK as a country and Britain's place in the world. It will also change the EU, reshape European geopolitics, affect NATO and change the US-UK and US-EU relationships, both internally and in respect of their place in the world.

The fact is that, after the Warsaw Declaration (July 2016), the issue of EUNATO cooperation became even more strategic. In fact, according to the 2015 Strategic Defence and Security Review (SDSR) ${ }^{20}$, the UK government has been committed to increasing the defence budget by 0.5 per cent a year in real terms until 2020-2021, to increase the equipment budget by 1 per cent in real terms annually, and to meet the NATO target of allocating 20 per cent of the defence budget to equipment, and research and development (R\&D). In addition, the Future Force 2020 (FF2020) envisages that British defence capabilities will lie in the deployment of a force of around 50,000 (Black et al, 2017:27).

For that purpose, the current UK commitments to NATO already include:

Provision of personnel to NATO standing commands and force structures (for example senior posts including Deputy Supreme Allied Commander Europe [DSACEUR] at Supreme Headquarters Allied Powers Europe [SHAPE], Maritime Commander [MARCOM] at NATO Northwood in Hertfordshire, and personnel and funding for the Headquarters Allied Rapid Reaction Corps [HQ ARRC] based in Innsworth); Capabilities and personnel to support NATO-led operations and exercises. Current examples include the provision of a framework battalion located in Estonia for NATO enhanced forward presence, the deployment of the Offshore Patrol Vessel HMS Mersey supporting NATO counter-migration activity in the Aegean and rotational participation in the NATO-led air policing of

20 Please see https:/www.gov.uk/government/publications/national-security-strategy-andstrategic-defence-and-security-review-2015 to access the 2015 National security strategy and strategic defence and security review 2015 (accessed 25 June 2018). 
the Baltic States and Iceland; and Commitment of troops and equipment to Alliance High Readiness Forces. Examples include NATO's Very High Readiness Joint Task Force (VJTF) (with the UK to be the lead nation in 2017), the NATO Maritime High Readiness Force and the NATO Response Force, as well as standing forces such as the NATO Standing Maritime and Mine Countermeasures Groups. (Black et al, 2017: 30).

Following Brexit, closer ties and a greater commitment towards NATO is expected to rebalance the security environment in Europe and

it is not unlikely that the European Allies will increasingly speak with one voice in NATO, since of all EU Member States the UK was always most opposed to this. Furthermore, it is the EU that has the instruments and the budgets to make possible the long-term comprehensive involvement in the political and economic sphere without which any military intervention in a country is meaningless. (Biscop, 2016: 14).

Moreover, as Beckusen (2016) argues “... a post-E.U. Britain might increase its role in NATO to make up for its declining influence in European capitals. Especially now that European governments worry about Russia's military buildup".

However, as the European Union committee of the House of Lords recently highlighted (2018:4), if the UK wants to maintain its influence in CSDP outside the EU structures, it is worth to consider both the negotiation of the observer status in the Political and Security Committee, as well as to invest in more resources in Brussels and in Member States' capitals. It is therefore crucial to be aware that if it's true that third countries might have some influence at an operational level of the CSDP missions and operations in which they participate, they have no formal role in decision-making or planning. Consequently, if the UK wants to keep a privileged role in the mandate or operational planning (which has been a red line in the existing model offered by the EU) there's the need to agree in a comprehensible consultation agreement ${ }^{21}$ in this issue between the EU and the UK to be implemented after Brexit.

${ }^{21}$ The European Commission's 'Internal EU27 preparatory discussions on the framework for the future relationship - Security, Defence and Foreign Policy (quoted in the House of Lords, 2018: 59 and available at https:/ec.europa.eu/commission/sites/beta-political/files/security defence_and_foreign_policy.pdf) - not only clarifies the Brexit impact regarding EU CSDP Missions and operations (with regard to third parties since third countries neither provide Operation Headqueartes for CSDP operations/missions nor cannot be lead-nation or have the post of Operation Commander or high level position in operations/missions.) but also reveals the immediate implications for the UK (such as in the case of the necessity of transfer of the Operation Headquartes of Operation Atalanta and the need to transfer the responsibility of the Operational Command of Althea - currently DSACEUR) and the EU interest (such as continued ability to plan and conduct CSDP missions and operation autonomously) as well as the options of the future partnership (three options seem available at this point: a Framework 
It is therefore necessary to wait for the negotiations to proceed and assess the degree of autonomy or cooperation in foreign and security policy-making processes: if the UK is to become an integrated partner (special status in the form of an EU+1), an associated partner (participation case by case in CSDP missions and operations), or a detached observer (privileging bilateral dialogue with specific EU member states) (Whitman, 2016:48-49) in the security and defence agenda.

\section{Conclusions}

While the negotiations take place, EU-UK relations will remain untouched. The output is expected to be both phased and sluggish, although the strong integration of European economies cannot face uncertainty for an indefinite period.

As there are no patterns nor models, speculation of any scenario will always be risky, but it is certain not only that the UK will continue to participate in the EU general meetings (though not on the negotiations on Brexit), as European laws will only be suspended when Brexit becomes official. Until then, the negotiations are focused in three points: first, on the conditions for access to the single market and tariff barriers with the European market; second, on the definition of a framework of trade agreements between the UK and the EU; and third, on freedom of movement for the people (EU member state nationals and UK nationals), in particular on the agreement on visas required for living and working, both for EU citizens in the UK and for those British who decide to live or work in any of the $27 \mathrm{EU}$ member states.

In addition, the European institutions and member states will certainly be reluctant to agree on an ultimate deal that creates a difficult precedent if other member states wish to follow the footsteps of the UK. That is why a special status which would allow the UK to continue fully in the internal market but opt out of all other areas would not only require a revision of the Community Treaties but would also be a prize that could easily be claimed by other member states.

All this clearly illustrates that security and defence is not in the tour de table. However, it is quite clear at this stage of the negotiations that neither the UK has interest to give up nor weaken the Euro-Atlantic security, nor to restrain its multilateral commitments towards NATO and the multinational projects regarding European and global security and defence.

We should not forget that the UK owns a permanent seat at the United Nations Security Council, and that it is a nuclear power and one of the four largest and most well-equipped European military powers. Regardless of whether the 
process will be soft or hard, Brexit can indeed represent a weakening of CSDP structures and components. However, by leaving one of the most powerful (but also controversial) suppliers to the formulation and implementation of the EU's foreign policy, new challenges and opportunities within the EU and its member states may arise leading to bigger efforts on behalf of the 27 member states to provide the material, financial, and human resources for projecting the EU as a credible strategic actor on the global arena.

In brief, what will be the impact of the withdrawal of the UK from the European Union? Faced with an apparent overlapping of the strategic environment and concerns of both organisations, not only is it expected that the UK continues to be engaged in CSDP Operations as a third country, but also to enhance NATO's commitments in the aftermath of the implementation of the 2016 Warsaw Declaration. The United Kingdom might leave the European Union, but it will remain a European state (also interested and engaged in CSDP). It will also continue to be a member of NATO, meaning that the British perspective is that the overlapping interests of both organizations will not collide after the Brexit. As the Brexit's impact will have to be assessed mostly on the multilateral level, it is important that the negotiation process avoids further fragmentation of the CSDP, which would undermine European security and its credibility within and outside the European Union. 


\section{References:}

Angelini, L. (2016) "Brexit is an Opportunity for EU Defence Policy". EU Observer, 8 July, <https://euobserver.com/opinion/134256>, (12 January 2018).

BBC (2016) "The EU Referendum: The Results in Maps and Charts", 24 June 2016, <http://www.bbc.com/news/uk-politics-36616028>, (20 February 2018).

Beckhusen, R. (2016) "Don't Panic Yet About the British Military After Brexit", Warisboring.com, 24 June, <https://medium.com/war-is-boring/dont-panicyet-about-the-british-military-after-brexit-57cac4a25979>, $(12$ January 2018).

Besch, S. (2016) "EU defence, Brexit and Trump: The Good, the Bad and the Ugly", Policy Brief, 14 December 2016, Centre for European Reform.

Biscop, S. and Coelmont J. (2010) "Permanent Structured Cooperation for Effective European Armed Forces", Security Policy Brief, Royal Institute of International Relations, March.

Biscop, S. (2016) "All or Nothing? European and British Strategic Autonomy After the Brexit", Egmont Paper 87, Royal Institute of International Relations.

Black, J., Hall, A., Cox, K., Kepe, M. and Erick Silfversten (2017) "Defence and security after Brexit - Understanding the possible implications of the UK's decision to leave the EU", Compendium report. RAND Europe. United Kingdom: Cambridge.

Calcara, A. (2017) "Brexit: what impact on armaments cooperation?", Global Affairs, 3 (2): 139-52.

Chalmers, M. (2017) "UK Foreign and Security Policy after Brexit". Briefing Paper, January 2017, Royal United Services Institute for Defence and Security Studies.

Faleg, G. (2016) “The Implications of Brexit for the EU's Common Security and Defence Policy", CEPS, <https://www.ceps.eu/publications/ implicationsbrexit-eu $\%$ E2\% $80 \% 99$ s-common-security-and-defence-policy $>$, (12 January 2018).

Heisbourg, F. (2016) "Brexit and European Security”, Survival, 58 (3), June July 2016: 13-22.

HM Government (2017) The United Kingdom's exit from and new partnership with the European Union, Presented to Parliament by the Prime Minister by Command of Her Majesty, February 2017. 
House of Lords (2018) "Brexit: Common Security and Defence Policy missions and operations". European Union Committee, 16th Report of Session 201719, Published by the Authority of the House of Lords.

Hughes, K. (2017) "Brexit Uncertainty, Scotland and the UK in 2018 - Four Scenarios", Policy Paper No 5, Scottish Centre on European Relations. October 2017.

Keohane, D. (2017) “Three's company? France, Germany, the UK and European defence post-Brexit", Real Instituto El Cano. $<$ http://www.realinstitutoelcano.org/wps/portal/rielcano_en/contenido?WC M_GLOBAL_CONTEXT=/elcano/elcano_in/zonas_in/ari1-2017-keohanethrees-company-france-germany-uk-european-defence-post-brexit>, (12 July 2018).

Koenig, N. and Walter-Franke, M. (2017) "France and Germany: spearheading a European security and defence union?” Policy Paper 202, (19 July 2017), Jacques Delors Institute.

Major, C. and Mölling, C. (2017) "Brexit, Security and Defence - A political problem, not a military one", Ulbrie, no 3, Swedish Institute of International affairs.

Morillas, P. (Ed) (2016) "The Brexit scenarios: Towards a new UK-EU relationship", CIDOB documents, 07 June 2016.

Oliver, T. (2015) "Europe's British question: the UK-EU relationship in a changing Europe and multipolar world", Global Society, 29 (3): 409-26.

Oliver, T. and Williams, M. J. (2016) "Special relationships in flux: Brexit and the future of the US-EU and US-UK relationships", International Affairs, 92 (3): 547-67.

Ondrejcsák, R. (2016) "Consequences of the Brexit vote to EU's security and defense policy", STRATPOL Policy Paper no 1.

Sky News (2017) "Britain's Article 50 Letter: The full text of the Brexit trigger", 29 March 2017, <https://news.sky.com/story/britains-article-50-letter-thefull-text-10817451>, (20 February 2018).

Uttley, Matthew R. H. and Wilkinson, B. (2016) "A spin of the wheel? Defence procurement and defence industries in the Brexit debates". International Affairs, 92 (3): 569-86.

Wallace, H. (2012) The UK: 40 Years of EU Membership. Journal of Contemporary European Research, 8 (4): 531-46.

Whitman, Richard G. (2016) "The UK and EU Foreign, security and defence policy after Brexit: integrated, associated or detached?", National institute economic review, No. 238: 43-50. 